\title{
Globalization, Computing and Their Political Impact
}

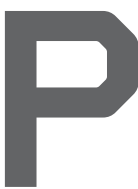

ERCHED AS WE are on the crest of the current tech and computing-enrollment boom, it is hard to remember the dark days of the early 2000s. The NASDAQ Index peaked on March 10, 2000, declining almost 80\% over the next two years. The stock-market crash in the U.S. caused the loss of $\$ 5$ trillion in the market valuations from 2000 to 2002. Computing enrollments in North America went into a steep dive. At the same time, the Internet enabled the globalization of software production, giving rise to the phenomenon of offshore outsourcing. There were daily stories in the media describing major shifts in employment that were occurring largely as a result of software offshoring. Combined with the dot-com bust, these reports raised concerns about the future of information technology (IT) as a viable field of study and work in developed countries.

In response to these concerns, ACM Council commissioned a Task Force in 2004 to "look at the facts behind the rapid globalization of IT and the migration of jobs resulting from outsourcing and offshoring." The Task Force, co-chaired by Frank Mayadas and myself, with the assistance of William Aspray as Editor, issued its report Globalization and Offshoring of Software (http://www.acm.org/globalizationreport) in 2006. The report concluded that there is no real reason to believe that IT jobs are migrating away from developed countries. The passing decade has vindicated that conclusion.

But while the report conceded that "trade gains may be distributed differentially," meaning some individuals gain and some lose, some localities gain and some lose; it was focused narrowly on the IT industry. Had we looked at the broader impact of globalization on the economy, we might have reached somewhat less sanguine conclusions. Globalization exerted tremendous competitive pressure on manufacturing in developed countries. It is instructive to examine the response to this competitive pressure, taking U.S. manufacturing as an example. To survive in the intensely competitive global economy, U.S. manufacturing had to increase its productivity dramatically, substituting technology for labor. U.S. manufacturing productivity roughly doubled between 1995 and 2015. As a result, while U.S. manufacturing output today is essentially at an all-time high, employment peaked around 1980, and has been declining precipitously since 1995. Neoclassical economists argue that when technology destroys jobs "people find other jobs, albeit possibly after a long period of painful adjustment." They are definitely right about the painful adjustment! The impact of globalization and automation over the past 20 years on working- and middleclass Americans has been quite harsh.

This impact has been succinctly captured recently by economist Branko Milanovic's "Elephant Curve" (see http:// prospect.org/article/worlds-inequality), which shows how people around the world, ranked by their income in 1998, saw their incomes increase by 2008. While the incomes of the very poor was stagnant, rising incomes in emerging economies lifted hundreds of millions of people out of poverty. People at the top of the income scale also benefited from globalization and automation. But the income of working- and middle-class people in the developed world stagnated over that period. In the U.S., for example, income of production workers today, adjusted for inflation, is at the level it was in in 1968! Ironically, automation is now reaching developing-world economies. Manufacturing employment in China peaked around 1995, where rising wages are driving automation, and a recent report from the International Labor Organization found that more than two-thirds of Southeast Asia's 9.2 million textile and footwear jobs are threatened by automation.

Until very recently, the global professional class, which includes most computing professionals, was somewhat oblivious to the plight of working- and middle-class people in developed countries. In fact, some have argued that this class lives in "an economic and cultural bubble." Political developments of the past few months have made it clear that the issue of shared prosperity cannot be ignored. It is now evident that the Brexit vote in the U.K., as well as the temporary rise of Bernie Sanders and the rise of Donald Trump in the U.S., were driven to a large extent by economic grievances. However the outcome of this month's U.S. presidential election, globalization and automation will remain policy issues of the utmost priority and will resist simplistic solutions.

Globalization and automation provide huge benefits to society, but their adverse effects cannot and should not be ignored. Technology is not destiny and public policy has a key role to play. As actors in and beneficiaries of this societal transformation, we have, I believe, a social responsibility that goes beyond our technical roles.

Follow me on Facebook, Google+, and Twitter.

Moshe Y. Vardi, EDITOR-IN-CHIEF

Copyright held by author. 